\title{
Algal Growth Experiments in the Baradla Cave at Aggtelek (Biospeleologica hungarica XXI)
}

\author{
By Erzsébet Kol ${ }^{1}$ )
}

\section{Introduction}

One of the most interesting problems facing speleobotanist today is the question of what energy source is used by the actively growing green algae which are found within caves throughout the world, since the eternally dark environment of the cave precludes the possibility of photosynthesis. Many algal species are known to be able, if necessary, to switch from their usual autotrophic assimilatory system to a heterotrophic nutrition if suitable organic materials are available (Chodat and Kol, 1934). In the present paper we are primarily concerned with those which apparently retain not only an autotrophic mode of life, but also their original green coloration.

\section{Materials and Methods}

In order to investigate this problem, several samples from axenic cultures of different algal strains present in the Kol collection of the Natural History Museum, Section of Botany, Budapest, were grown for varying periods of time in both light and dark, including cave environments. The cultures were inoculated into tubes on agar $+1 / 3$ Detmer-medium. For each experiment, three parallel cultures from each strain were included for each varying environmental condition. The laboratory investigations were carried out in the Natural History Museum, Section of Botany.

A total of 108 algal strains were used in these experiments. Cyanophyta was represented with 53 separate strains, Chlorophyta with 35, and Chrysophyta with 20. A list of the individual strains is found below. In the following work the strains will be denoted by their respective accession numbers in the Algotheca.

1) Botanical Division, Natural History Museum, Vajdahunyadvár, Budapest, Hungary. 


\title{
List of Algae Used in Experiments
}

\author{
CYANOPHYTA
}

230. Amorphonostoc paludosum (Kg.) Elenk.

23. Amorphonostoc punctiforme (Kg.) Elenk.

214. Amorphonostoc punctiforme (Kg.) Elenk.

215. Amorphonostoc punctiforme (Kg.) Elenk.

177. Chlorogloea microcystoides Geitler

176. Hammatoidea normanni W. et G. S. West

81. Lyngbya lagerheimii (Möb.) Gom.

53. Nostoc sp.

216. Nostoc sp.

218. Nostoc sp.

231.a. Oscillatoria acutissima Kuff.

234.a. Oscillatoria nigra Vaucher

122. Phormidium autumnale (Ag.) Gom.

122.a. Phormidium autumnale (Ag.) Gom.

223. Phormidium autumnale (Ag.) Gom.

225. Phormidium autumnale (Ag.) Gom.

225.x. Phormidium autumnale (Ag.) Gom.

233. Phormidium autumnale (Ag.) Gom.

29. Phormidium foveolarum (Mont.) Gom.

29.a. Phormidium foveolarum (Mont.) Gom.

138.a. Phormidium foveolarum (Mont.) Gom.

168. Phormidium foveolarum (Mont.) Gom.

172. Phormidium foveolarum (Mont.) Gom.

172.a. Phormidium foveolarum (Mont.) Gom.

217. Phormidium foveolarum (Mont.) Gom.

217.x. Phormidium foveolarum (Mont.) Gom.

217.xx. Phormidium foveolarum (Mont.) Gom.

144. Phormidium laminosum (Ag.) Gom.

144.a. Phormidium laminosum (Ag.) Gom.

144.b. Phormidium laminosum (Ag.) Gom.

206. Phormidium laminosum (Ag.) Gom.

209. Phormidium laminosum (Ag.) Gom.

209.a. Phormidium laminosum (Ag.) Gom.

209.b. Phormidium laminosum (Ag.) Gom.

209.c. Phormidium laminosum (Ag.) Gom.

209.d. Phormidium laminosum (Ag.) Gom.

209.e. Phormidium laminosum (Ag.) Gom.

211. Phormidium laminosum (Ag.) Gom.

211.a. Phormidium laminosum (Ag.) Gom.

309.a. Phormidium laminosum (Ag.) Gom.

309.b. Phormidium laminosum (Ag.) Gom.

11. Phormidium molle (Kg.) Gom.

227. Phormidium molle (Kg.) Gom.

212. Phormidium molle (Kg.) Gom.

234. Phormidium molle (Kg.) Gom.

226. Phormidium uncinatum (Ag.) Gom.

136. Plectonema sp.

254. Plectonema tenue Thur. 
62. Stratonostoc commune (Vaucher) Elenk.

47. Stratonostoc linckia (Roth) Elenk.

87.a. Stratonostoc linckia (Roth) Elenk.

207. Stratonostoc linckia (Roth) Elenk.

208. Stratonostoc linckia (Roth) Elenk.

\section{CHLOROPHYTA}

174. Ankistrodesmus falcatus (Corda) Ralfs

28. Chlamydomonas intermedia Chodat

149. Chlamydomonas intermedia Chodat

82. Chlorella miniata (Naeg.) Oltm.

101. Chlorella pyrenoidosa Chick

132. Chlorella pyrenoidosa Chick

143. Chlorella pyrenoidosa Chick

204. Chlorella pyrenoidosa Chick

63. Chlorella vulgaris Beyer.

66. Chlorella oulgaris Beyer.

91. Chlorella oulgaris Beyer.

106. Chlorella oulgaris Beyer.

124. Chlorella vulgaris Beyer.

135. Chlorella vulgaris Beyer.

138. Chlorella vulgaris Beyer.

138.b. Chlorella vulgaris Beyer.

146. Chlorella pulgaris Beyer.

151. Chlorella vulgaris Beyer.

159. Chlorella vulgaris Beyer.

159.a. Chlorella oulgaris Beyer.

162. Chlorella vulgaris Beyer.

166. Chlorella vulgaris Beyer.

219. Chlorella vulgaris Beyer.

233.a. Chlorella vulgaris Beyer.

68. Chlorella sp.

81.a. Chlorella sp.

205. Chlorella sp.

222. Chlorococcum humicolum (Naeg.) Rabenh.

154. Chlorococcum infusionum (Schrank) Menegh.

240. Chlorococcum sp.

5. Cystococcus humicola Naeg. em. Treb.

280. Dictyococcus cinnabarina (Kol et F. Chodat) Vischer

10. Hormidium flaccidum A. Br. sens. ampl.

65. Scenedesmus obliquus (Turpin) Kg.

230.a. Stichococcus bacillaris Naeg. sens. ampl.

\section{CHRYSOPHYTA}

\section{Xanthophyceae}

309. Botrydiopsis arhiza Borzi

37. Botrydiopsis minor (Schmidle) Chodat

216.a. Chlorocloster minimus Pascher

227.x. Ellipsoidion oocystoides Pascher 
227.xx. Ellipsoidion oocystoides Pascher

228. Ellipsoidion oocystoides Pascher

43. Ellipsoidion regulare Pascher

213. Ellipsoidion $\mathrm{sp}$.

213.a. Ellipsoidion $\mathrm{sp}$.

201. Monodus dactylococcoides Pascher

49. Monodus subterranae Boye-Petersen

50. Monodus subterranae Boye-Petersen

221. Monodus subterranae Boye-Petersen

232. Monodus subterranae Boye-Petersen

229. Pleurochloridella botrydiopsis Pascher

181. Pleurochloris commutata Pascher

87. Raphidiella fascicularis Pascher

\section{Bacillariophyceae}

224. Nitzschia palea (Kg.) W. Smith

231. Nitzschia palea (Kg.) W. Smith

Five different experimental series were performed on the algal strains.

1. Orientation experiments to determine which of the strains were best suited for our purposes. Ninetyfive algal strains were kept in darkness in the laboratory for 268 days (Table I.).

2. Parallel experiments with 27 algal strains, in the cave and in darkness in the laboratory, for 204 days, followed by 245 days in light for the cave cultures (Table II).

3. Parallel experiments with 103 algal strains, in the cave and in the laboratory darkness for 365 days (Table III).

4. Experiments in the cave environment for 175 days with 26 algal strains, which had previously been cultured under light conditions in the laboratory for 139 days (Table IV).

5. Parallel experiments with 27 algal strains in the cave, in a cellar and in darkness in the laboratory for 420 days and followed by exposure to light in the laboratory for 158 days (Table V).

The results of the experiments are summarized in Tables I-V, in which the degree of development of the cultures is denoted in two ways: 1. The surface magnitude of the algal thallus is measured in mm. ${ }^{2}$ or $\mathrm{cm}^{2} ; 2$. The overall growth in the culture is denoted as from 1 to 5 . (Details are found in Table I).

\section{Results}

\section{Orientation Experiments}

Ninetyfive strains were used, 44 Cyanophyta, 33 Chlorophyta and 18 Chrysophyta. Cultures for experiments in darkness were placed in 
boxes especially prepared for this purpose, the inside of which was lined with black paper. The cultures themselves were wrapped with a double-layered black cloth before placement into the boxes, the covers of which had an overlapping rim of several centimeters. This arrangement already retrains light penetration, but for even further security, the boxes were then wrapped with heavy duty black paper. Control cultures were placed in the same laboratory, under the same temperature conditions, under light. Thus, both of the series had the same environmental conditions with the exception of light. The purpose of this orientation was to separate and select those algal strains which can live in darkness and would thus prove to be the most suited for the purpose of the subsequent experiments. The cultures were kept in the boxes for a period of 268 days (1/22/60-10/18/60) after which they were removed, observed, and for another 150 days (10/18/60-6/ $25 / 61$ ) were kept in light in the laboratory.

It can be seen from Table I that most of the algal strains survived this long period of darkness, retained their green color, and many of them even showed satisfactory growth. However, some of the strains perished completely, in the dark, while in some cases, although the strains survived, their color changed from green to brownish or yellowish-green. In those strains which retained their green color some apparently actively grew, and in some cases only the original inoculum survived, as indicated by a lack of thallus development.

As much variation occurred in the reactions of the algae to the 150 days of light environment as to the 268 days of darkness. As can be seen from Table I, some of the algae developed with great intensity in the light, a few strains which had barely survived in the darkness underwent a vivid growth during this 150 days, a good number of the strains which had just survived the rigors of darkness did not improve in the light and some even perished. A few particularly interesting strains which had showed some development during the first part of this experiment quit growing in the light as through the light itself were actually a restraining factor. (\# 146, 149, 217.)

From Table I it is clear that light requirement for growth, or the ability to survive in lack of it, is not so much a characteristic of a species as it is of a single algal strain. We can see that in the same species (note Chlorella sulgaris, Phormidium foveolarum, Phormidium laminosum and Nostoc) some strains have shown quite satisfactory growth in darkness while others completely perished.

During the entire time of this experiment, out of the total 95 strains, 14 showed significant growth and 12 perished. 
2. Parallel Growth Experiments in the Cave and in the Laboratory in Darkness and in Light

Twentyseven selected strains of algae were kept in darkness both in the cave and in the laboratory for a period of 204 days $(4 / 1 / 60-10 /$ $22 / 60)$. After their removal from the dark environments, they were examined and placed in the light for a period of 245 days $(10 / 22 / 60-6$ / 25/61).

The results of these experiments are summarized in Table II, from which it becomes clear that some algal strains thrived well in the cave and showed excellent development. Others, however, barely stayed alive. Certain strains developed in the darkness of the cave better than in the dark in the laboratory, while others showed better development in the dark in the laboratory than in the cave. The strains in the former group apparently are able to tolerate the lack of light much better in the cooler cave environment whereas those in the latter group thrived better in the dark under the laboratory conditions at the higher temperature (room) which this provided for them.

In both experimental series the twentyseven strains were kept in total darkness for a period of 204 days and even under these conditions only four perished completely while ten showed excellent development.

The results of culturing the algae for an additional 245 days after their removal from the cave or after the removal of the wrapper in the laboratory are also compiled in Table II. Purposes of these studies were two-fold: 1 . to establish whether or not the strains which were weakened in the cave or in the darkness of the laboratory will be able to regenerate when placed in light; 2 . whether or not the strains which possibly changed to heterotrophism due to the long lightless condition will be able to revert to autotrophism. These experimental series at the same time served as a check to demonstrate that the strains kept in the cave or in the laboratory darkness were still alive. Some strains which showed only a small development or remained barely alive in the cave when placed to the light showed an excellent development. In general those strains which developed well in the cave retained their developmental intensity when exposed to light. Two strains, number 50 and 122 , in spite of the fact that they developed quite well in the cave lost this developmental intenstity in the light culturing. Two other strains, number 43 and 49 which, however, were barely viable when recovered from the cave, perished after light exposure. Some other factors which are not mentioned here may also played a role in this case. 
3. Parallel Experiments in Darkness in Cave and Laboratory

In these experiments parallel cultures of 103 algal strains were prepared for growth determinations in the cave and in the darkness of the laboratory for an entire year (12/19/60-12/20/61). The results are found in Table III.

Among the 103 cultures kept in the cave, ten showed significant growth and ten perished. In the laboratory six strains showed significant growth, none of these were the same as those developing well in the cave, and these six showed a smaller thallus than the very well developed thalli of the cave growers. In the darkness of the laboratory twelve strains died, again none of the same strains which perished in the cave. Strain \# 87 showed excellent development in the cave, but perished in the laboratory. We can generalize that a greater percentage of the cave cultures thrived, they established larger thallil, and a smaller percentage died, compared to the laboratory cultures.

Some general color differences can be seen between the two environments. Although the cultures all, in both biotypes, kept a green color, the fine shading had a general trend to dark green and brownish-green in the cave, with the exception of the strains of Phormidium which become a yellowish-green (see Table III). The laboratory cultures tended much more to true green and light green. Nitzschia palea (strains 224, 231) kept their brownish color in both environments.

The major differences in environmental parameters that the cultures had to contend with were the greater humidity of the cave, its lesser temperature, and the possible radiating energy that can be found in a cave.

\section{Experiments in Cave, with Cultures Previously Grown in Light}

Twentysix algal strains were used. Inoculated on February 15, 1961, these strains were grown in light for five months, and then were placed in the cave environment for 175 days (on July 20th, 1961). The purpose was to determine the reaction of the cultures, after having attained a good growth, in the laboratory to the cave environment. In previous experiments, the cultures were placed into the dark environment, either laboratory or cave, within a few days after inoculation, while in this instance they were placed into the cave after growing them during the best vegetation period in the light, i.e. spring and summer while still during the vegetation period. The results of these experiments are summarized in Table IV. 
Again, even among these few strains, the results are quite varying. A total of 14 out of the 26 strains acclimatized easily and retained their intensity of development. Five stopped development, probably due to some hindering circumstance of the cave, although the original thalli, in their original sizes, remained alive. One culture died and several became ill.

The general health pattern and developmental trends of the cultures is indicated not only by the size of the thallus but also by coloration changes. In every instance, such a change signifies a change in the health pattern of the culture. In poor health it seems that the green color fades, and often the coloration changes to brownish or yellowish. Those particular species which usually form large amounts of carotene, tend to produce even more in the cave environment and their color turned often to a stronger yellow, or reddish-yellow, as can be seen in Table IV, especially strains $65,280$.

From this Table it becomes evident that it is immaterial for these microorganisms, from the viewpoint of their ability to grow and develop in the cave, whether or not they have lived under light and have already developed a thallus of some size or whether they are placed in darkness immediately after inoculation with only a few cells in the medium. Their adaptation seems to be identical in either case, although there are a few strains which seem better able to endure cave conditions if placed there as very young cultures, and have not been grown in light first.

\section{Parallel Experiments in Cave, Laboratory and Cellar in Darkness, Followed by Light Culturing}

For 420 days (4/25/62-6/30/63) twentyseven algal strains were kept in darkness under the conditions described below, after which they were removed from the darkness, examined and placed in light for 158 days (6/30/63-11/26/63). In each instance at least three parallel cultures were used.

A. Cultures in formly sealed metal boxes in the cave.

B. Cultures placed in the cave without wrapping.

C. Cultures placed in a dark, damp cellar, after having been wrapped in several folds of black paper and textile.

D. Cultures placed in a dry cellar, wrapped as in C.

E. Cultures kept in dark metal boxes, in the laboratory at room temperature (thus at a higher temperature than A through D).

F. Cultures placed under light, in the laboratory. 
Some algal strains showed good development even when sealed within metal boxes in the cave, and some exhibited even better development under such conditions than when they were freely placed in the cave. However, other strains barely survived in the box. Many of the algae also showed good development when freely placed, while some grew equally well in both biotopes $(28,138,280)$.

The available moisture was identical for both algal groups due to the fact that those which were freely placed in the cave could directly utilize the moist air of their surrounding, while the others, placed in boxes, had at their disposal the moisture of the medium which was shielded from evaporation by the lid. Therefore, the cultures in the boxes had available to them the required quantity of moisture.

After removal from darkness these cultures were kept for 158 days under light, during which the phenomenon already known from Experiment 2 repeated itself, namely that those strains which in darkness could barely survive, when placed under light showed good development (See Table V); while those which exhibited good growth already when in the dark developed with even greater intensity under light.

Let us now see, how these same algal strains behaved in the darkness of the cellars under different moisture conditions. It should be noted here that the cultures which were placed in the cellars were not sealed in boxes, therefore, the moisture content of the cellars could reach these cultures directly. (Series C and D.)

Surprisingly only five algal strains showed better development in the damp cellar while eight strains thrived better in the dry one. Some apparently could not adapt well to either place, but merely survived, and strains nos. 149 and 162 died in the cellars.

In general, among the cultures of algae in the cave, as compared with those in the cellars, more strains were seen growing with greater intensity, even when sealed in a metal box. Strain no. 28 , showed very good development in series A and B, while in the damp cellar (C) it could merely survive. Although this strain did develop in the dry cellar (D) it was not to the same extent as when in the cave. Still a few strains showed better development in the cellar than in the cave.

We may conclude from the above experiments that in the cave there is some energy source available to the algae which is not present in the cellar or laboratory. This energy source has to be of the type which can penetrate a metal box, since some algal species showed better development in the boxes. Therefore, this energy can only be some kind of an emissive energy. Whether it is a readioactive radiation or some other type which is not known at the present must be ascertained by future experiments. 
Series $\mathrm{E}$ was kept in the laboratory in dark boxes at a higher temperature, i.e., room temperature, than the temperature of the cave or cellars. More of the algal strains showed better development in the cave, and even in the cellars, than those which were kept in the laboratory darkness at higher temperatures. The most resistant strain was no. 28, because under all six circumstances this strain showed the greatest development. Those strains which could hardly survive when kept in the dark in the laboratory became more-or-less regenerated when placed under light.

Series A-E of Experiment 5 were kept in darkness for 420 days, and thereafter under light for 158 days.

Series $\mathrm{F}$ was kept under light at room temperature in the laboratory for 578 days. Even under this latter condition, the intensity of development of the different algal strains varied; eight strains showing high development, small development displayed by six, and three $(28,151$ and 216) barely surviving.

It can be seen from the above that there seem to exist both photophilic and also sciophilic, that is dark demanding algal strains.

\section{Discussion}

\section{A. General Considerations}

It was already mentioned that there must be some kind of radiation in the cave which serves as an energy source for these plants. However, as it can also be seen from the above experiments, the simple existence of such energy is inadequate, since it is also necessary that the organisms, in this case the algae, should have the capacity of absorbing and utilizing such radiation as their source of energy. It can be said that the existence of indigenous life in caves is based on this fact, and serves also as a species selective factor. The adaptability of the individual living organism may also play an important role; those algal strains which can easily switch from an autotrophic to a heterotrophic existence can more-or-less utilize the energy source provided by the cave, and are able to survive and develop there. The algal strains which are unable to utilize the energy source available in the cave, but are hardy and able in general to bear unfavorable conditions, such as dessication, lack of light, etc. can survive, but not develop. Also important is the individual character of the organism, in this case the algal plant, how soon it is able to acclimatize, that is whether it is able to change its nutritional system under the force of the changed environmental conditions. 
The time period provided for these experiments in order to study and judge the behavior of algal strains under different conditions was undoubtedly sufficiently long and in some cases perhaps was even too long. The experiments were set up to include at least one vegetation period, i.e., spring and summer.

The cultures kept in the cave in many cases show deviations from the usual: (1) in color, the green color of the strains tends towards a yellowish, quite often brownish color, whereas the Cyanophyta become vivid bluish-green; (2) usually the pyrenoids of the cells do not develop, little or no starch is found in the cells; (3) while vigorous cell division occurs, the developing cells usually are very small; (4) in the filamentous algae the filaments are often disintegrating; in the Cyanophyta the mucous sheath of the filaments are well developed; (5) in the yellow colored strains carotene formation is higher than usual.

At the present time it is not known which species of the different algal groups can bear darkness better, this ability is, however, probably an individual characteristic. The plants of the caves belong mainly to the groups of edaphic and terrestrial algal species.

\section{B. Energy Sources Available to the Cultures During the Experiments}

Chodat and Kol (1934) carried out different experiments with the algal strains in R. Chodat's Algotheca at the Botanical Institute of the University of Geneva, Switzerland. The strains were kept in darkness and under light, in air and in vacuum, in inorganic medium, both with and without sugars. Attention is called only to the results of those experiments which seem to be relevant to the present studies and which are mainly concerned with the autotrophic and heterotrophic nutrition of the different algae under varying environmental conditions.

According to this paper (loc. cit.p. 5 Tab. I) some algal species could not only live in a vacuum and on inorganic medium in the laboratory but also develop and undergo cell division if kept in light. Under aerobic condition and in darkness (loc. cit. p. 10) there was cell division occurring to some degree even in the sugarless, inorganic medium, while under the same conditions but with a medium contaminated with sugar the rate of cell division of certain species dropped to from one-half to one-quarter of that shown under light. In the latter case, in the lack of light, the lower rate of cell division can be attributed to a change to heterotrophic nutrition. One can also see from this Table (loc. cit. p. 10. Tab. III) that cell division is significantly reduced in 
vacuum that is in unaerobic conditions, and darkness, that cell division in certain species kept in medium containing sugar is slight, and it disappears completely on the inorganic medium.

In the experiments referred to above the algae were provided with different energy sources as shown below:

$\mathrm{A}=$ energy utilized by photosynthetic assimilation, with the aid of chlorophyll, through autotrophic nutrition.

$H=$ energy sources provided and located in the medium itself.

$\mathrm{J}=$ energy liberated by anaerobic fermentation of different materials within the cells themselves in the vacuum.

$\mathrm{R}=$ energy developed by the algae themselves in the presence of oxygen and respirable materials.

Therefore, the cultures which were kept under light were provided with energy sources $\mathrm{A}+\mathrm{H}$, for those in darkness and inorganic, sugar free medium, the energy source was $\mathrm{R}$, and for cultures in sugar containing, therefore actually organic, medium and in darkness the energy sources $\mathrm{R}<\mathrm{H}$ were available. Therefore, accordingly (loc. cit. p. 13 Tab. IV) the carbon uptake can occur in both autotrophic and heterotrophic manner. In the presence of light green algae assimilate in autotrophic manner. On inorganic medium and in the absence of light, the functioning of the algal cells is reduced mainly to respiration, however, if in the medium organic material, like sugar, is available, a change to heterotrophic nutrition may take place.

In the case of algae in the caves and also those cultured in the cave, the medium contained purely inorganic salts and agar-agar. Therefore, obviously in this case the energy source needed from the medium for a heterotrophic nutrition was not available to the algal cells.

The experiments carried out in the cave in darkness show that: (1) The organic materials probably present in the cave could not have served as an energy source for a heterotrophic nutrition for the algal cultures. (2) Neither did, as was supposed by some that the energy liberated through chemosynthesis by different bacteria living in the cave, serves as an energy source, since the cultures were kept sterile, sealed with cotton plugs, which were intact when removed from the cave, therefore, no bacterial product could have penetrated to the algal cells.

In view of this, one must suppose that the algal cells have the capacity to intercept an as yet unknown radiation or radiating energy probably existing in the cave and to utilize it further for their life functioning. In my opinion, this capacity is a strictly individual characteristic of the different algae, as also proven by the experiments described herein. 
C. Different Influencing Factors during the Experiments

During the experiments, in the varying environmental conditions, different factors influenced the nutrition of the different algal strains:

1. Medium: $1.5 \%$ agar-agar $+1 / 3$ Detmer solution $=\mathrm{T}$.

2. Moisture content of the medium $=-\mathrm{V}$; degree of humidity of the air $=+\mathrm{V}$.

3. Temperature in the laboratory $=+\mathrm{H}$; the lower temperature of the cave $=-\mathrm{H}$.

4. Light $=\mathrm{F}$.

5. Aerobic conditions $=+\mathrm{L}$; aerobic conditions in tin boxes $=-\mathrm{L}$.

Among these factors, only the medium is constant in every case, all the other factors vary according to the different experimental conditions. Experiment 1: $+\mathrm{T},+\mathrm{V},+\mathrm{H},+\mathrm{L}$ and $-\mathrm{F}$.

Experiment 2:

a) $+\mathrm{T},+\mathrm{V},+\mathrm{L}$ and $-\mathrm{F},-\mathrm{H}$.

b) $+\mathrm{T},+\mathrm{V},+\mathrm{L},+\mathrm{H}$ and $-\mathrm{F}$.

c) $+\mathrm{T},+\mathrm{V},+\mathrm{L},+\mathrm{H},+\mathrm{F}$.

Experiment 3:

a) $+\mathrm{T},+\mathrm{V},+\mathrm{L}$ and $-\mathrm{F},-\mathrm{H}$.

b) $+\mathrm{T},+\mathrm{V},+\mathrm{L},+\mathrm{H}$ and $-\mathrm{F}$.

Experiment $4:+\mathrm{T},+\mathrm{V},+\mathrm{L}$ and $-\mathrm{F},-\mathrm{H}$.

Experiment 5:

A. $\quad+\mathrm{T}$ and $-\mathrm{V},-\mathrm{L},-\mathrm{F},-\mathrm{H}$ (minimum).

B. $+\mathrm{T},+\mathrm{L},+\mathrm{V}$ and $-\mathrm{F},-\mathrm{H}$.

C. $+\mathrm{T},+\mathrm{L},+\mathrm{V}$ and $-\mathrm{F},-\mathrm{H}$.

D. $+\mathrm{T},+\mathrm{L}$ and $-\mathrm{F},-\mathrm{H},-\mathrm{V}$.

E. $+\mathrm{T},+\mathrm{L},+\mathrm{V},+\mathrm{H}$ and $-\mathrm{F}$.

$\mathrm{F}$. $+\mathrm{T},+\mathrm{V},+\mathrm{L},+\mathrm{H},+\mathrm{F}$ (maximum).

The minimal life conditions, from point of view of energy sources, is available to the algae during Experiment 5, group A, since only the medium remains unchanged. There is no light in the cave, the humidity of the air cannot penetrate into the box, the air itself is limited somewhat by the box, and the algae are kept at the lower temperature of the cave.

The algal strains of Experiment 5, group F, are living in preferred, maximal conditions, as, by the way, did the other strains which were kept under light. However, strains of group $\mathrm{F}$ were living under the most favorable conditions as compared with the others, since they were placed in light immediately after inoculation, while the others were kept first in darkness and only thereafter in light. 
According to the present day concepts, one can speak of autotrophic nutrition only for cultures kept under light. Those cultures freely placed in the cave in darkness may have accidentally received some small amount of illumination and retained their autotrophism. However, no light was available for the cultures which were kept in complete darkness in the laboratory, cellar and in the cave, nor to those kept in tin boxes in the cave. In view of the fact that no organic material was present in the medium, it being constituted of only the inorganic salts of Detmer solution and the agar-agar, the plants could utilize only the energy source available in this inorganic medium and/or those provided by the cave.

Certain algal strains have specific chlorophylls differing from those of flowering plants, which may be a contributing factor to the fact that some algae are able, even in total darkness to produce chlorophylls and continue their development.

It is a well known fact that if organic material, such as carbohydrates, are available in the medium, some algal species are capable of utilizing them. In these cases, in the lack of light the algae can easily change to a heterotrophic nutrition. During these cave experiments however, we dealt solely with an inorganic medium, though some algal strains do react to a decrease in the humidity of air, this is not the critical factor here, nor is it, as it can be seen from the previous experimental series, the low temperature, nor the occasional deficiency of air, but the critical factor is the light, that is lack of light, or radiation of some type substituting for light. Wheter this radiation is or is not radioactive, will be proven by further experiments.

It is probable that more algal strains will become located in those places of the cave where illumination sometimes reaches the plant since in those places even such strains can survive and develop which are unable to bear total and permanent darkness.

Fehér's (1954) experiment, in which he kept algal cultures for 1-2 years, in complete darkness, in 1-2 meters in the earth is a further proof that some algal strains can easily endure a prolonged lack of light. His cultures survived, retained their green color, and even multiplied.

The hypothesis that the algae in the cave use as food organic material partially decomposed by bacteria or lower fungi is not applicable in our case because in the experiments presented here no such nutrients could have reached the algal cultures.

Although even a few decades ago it seemed very unlikely that green plants could inhabit the darkness of the caves, today we know from many experiments (Palik 1960a, Claus 1955, Suba 1957), that several 
algal species live in caves, and that the spores of even more can be found there. I shall not deal in this paper with the question of how these spores got into the caves.

It is quite probable that the algal species found in various caves vary according to the different light conditions found in them. Some algal strains can utilize even the most insignificant amount of light, while others are able to tolerate its complete absence. Many species representing the edaphon can be found in the caves which points out that other factors besides light may influence the populating of caves. Thus, the rock structure, the chemical composition of water, the humidity and temperature of the air, etc., all have a selective influence. The microorganisms found in ice caves are completely different from those which occur at the higher temperature of the dripstone caves. Those algal species which can be found in a cave only as spores, even if it is possible to culture them artificially when removed from the cave, cannot be enumerated as being part of the cave's microvegetation. Only those algal species which lead a vegetative life in the cave and which also multiply there belong to its flora. In my opinion one can enumerate as the organisms of a certain biotope only those which spend a significant portion of their vegetative and reproductive life cycle in this biotope.

It can also be seen from this paper, that in general algal strains belonging to the Cyanophyta, and to the edaphic and terrestrial Chlorophyta and Chrysophyta are those which showed the best development in darkness (Nos. 29, 47, 50). Among the Chlorophyta Chlamydomonas and Chlorella species with several strains tolerated the best the lack of light. Among the Chrysophyta, Monodus subterranea (Nos. 88, 50) and the Ellipsoidion species, among the Cyanophyta the species of Phormidium adopted best to darkness. According to Table V, among the species kept in darkness in the boxes in the cave No. 81 Lyngbya lagerheimii; No. 50. Monodus subterranea; Nos. 29, 29a. Phormidium foveolarum; No. 28. Chlamydomonas and No. 66. Chlorella species showed the highest development.

Whether there are exclusively cave dwelling algal species one does not know at present. Research in cave biology has to go a long way before it will have a real knowledge about the microorganisms living in the caves and will have ascertained their environmental conditions.

\section{ACKNOWLEDGEMENT}

I would like to express my sincere appreciation to Dr. Endre Dudich, Professor of Zoology and Director of the Cavebiological Laboratory at Aggtelek of the L. Eötvös University of Budapest for having made these experiments possible by delivering and placing the cultures within the cave. 


\section{SUMMARY}

The author kept 108 algal strains (Cyanophyta 53, Chlorophyta 35, Chrysophyta 20), of axenic cultures from the Kol-Algotheca in the Botanical Division of the Hungarian National Sciences Museum in the Baradla Cave, at Aggtelek (Hungary) in darkness for 204-420 days under different environmental conditions.

The experiments have proven that several algal strains can tolerate well the complete absence of light. Furthermore, that some algal strains show intensive development even under such conditions. These axenic cultures kept in the cave in metal boxes on inorganic medium have shown that the energy source used by these green colored algae is not some byproduct of chemotrophic bacteria, nor is it available organic material, but that it must be some kind of radiation which is able to penetrate even the metal boxes.

The ability to adapt to the conditions existing in a cave is not a general characteristic of algal species, but is the capability of individual algal strains within that species. Most probably the algae living in the caves are aerophytes, terrestrial forms, and also some belonging to the edaphon.

The cells were found to be smaller in the algae kept in the cave, there was almost no starch deposition in the cells, the pyrenoids were barely discernible, but the development of carotenes was more intense.

Whether there are specific cave dwelling algal strains must be determined by future algological research conducted in caves. The composition of the algal floras of the caves may be equally dependent upon the chemical and physical characteristics of the biotope, as is the case in every other biotope.

\section{ZUSAMMENFASSUNG}

108 Algenstämme (53 Cyanophyta, 35 Chlorophyta und 20 Chrysophyta), die aus axenen Kulturen der Kol-Algensammlung der Botanischen Abteilung des ungarischen Nationalmuseums der Wissenschaften beimpft wurden, wurden in der Baradlahöhle bei Aggtelek (Ungarn) während einer Zeitdauer von 204-420 Tagen unter verschiedenen Standortbedingungen kultiviert.

Die Versuche haben gezeigt, daß eine Anzahl von Algenstämmen vollständige Dunkelheit (Fehlen von Licht) sehr gut vertragen können. Darüber hinaus zeigen einige dieser Stämme unter den genannten Bedingungen eine intensive Entwicklung. Diese axenen Kulturen, die in der Höhle in Metallgefäßen auf anorganischem Medium gehalten wurden, haben gezeigt, daß die Energiequelle, die von diesen grüngefärbten Algen genutzt wird, kein Nebenprodukt chemotropher Bakterien ist, noch daß es sich dabei um verwertbares organisches Material handelt; es muß vielmehr irgendeine Strahlungsenergie sein, die in der Lage ist, selbst Metallbehälter zu durchdringen.

Die Fähigkeit, sich den in der Höhle herrschenden Bedingungen anzupassen, ist kein allgemeines Charakteristikum der Algenarten, sondern beruht auf speziellen Eigenschaften individueller Algenstämme innerhalb einer bestimmten Art. Höchstwahrscheinlich sind die in den Höhlen lebenden Algen Aerophyten, terrestrische Formen, oder sie gehören zum Edaphon.

Bei Algen, die in den Höhlen gehalten wurden, waren die Zellen kleiner, enthielten kaum Stärke in den Zellen, und die Pyrenoide waren kaum sichtbar. Demgegenüber war die Entwicklung von Karotinen sehr viel intensiver.

$\mathrm{Ob}$ es spezifische höhlenbewohnende Algenrassen gibt, muß durch weitere algologische Untersuchungen in den Höhlen entschieden werden. Die Zu- 
sammensetzung der Algenflora in den Höhlen dürfte in gleicher Weise von den chemischen und physikalischen Eigenschaften des Biotops abhängen, wie dies auch bei allen anderen Biotopen der Fall ist.

\section{REFERENCES}

Caumartin, V. (1957) - La microflora des cavernes. Not. Biospeleol. 12: $59-64$.

- (1959) - Quelques aspectes nouveaux de la microflore des cavernes. Ann. Spéléol. 14: 147-157.

Chodat, F., and Kol, E. (1934) - Quelques algues nouvelles des sols et de la neige du Parc National Suisse Engadine. Bull. Soc. Bot. Genève 25: 1-14.

Claus, G. (1955) - Algae and their Mode of Life in the Baradla Cave at Aggtelek. Acta Bot. Acad. Sci. Hung. 2: 1-26.

- (1959) - Concerning the Algal Flora of the Peace Cave at Aggtelek in Hungary. IX. Intern. Bot. Congr. Proc. 2A: 75.

- (1960) - Re-evaluation of the Genus Gomontiella. Rev. Algol. Nouv. Ser. 5: 103-111.

- (1962a) - Data on the Ecology of the Algae of Peace Cave in Hungary. Nova Hedwigia 4: 55-79.

- (1962b) - Beiträge zur Kenntnis der Algenflora der Abaligeter Höhle. Hydrobiologia 19: 192-222.

- (1964) - Algae and their Mode of Life in the Baradla Cave at Aggtelek II. Intern. J. Speleol. 1: 13-17.

Dudich, E. (1932a) - A barlangok biologiai osztályozása (Biological Classification of Caves) Barlangvilág 2:1-8.

- (1932b) - Biologie der Aggteleker Tropfsteinhöhle Baradla in Ungarn. $1-246$.

- (1955) - A barlang mint gyógytényezö (The Cave as a Factor in Curing) Födlr. Közl. 85: 353-359.

- (1958) - Klassifikation der Höhlen auf biologischen Grundlagen. Mitt. Höhlen-Karstforsch. 3: 35-43.

- (1959) - Barlangbiologia és problémái (Cave Biology and its Problems). Magy. Tud. Akad. Biol. Csop. Közl. 3: 323-357.

- (1960) - Das höhlenbiologische Laboratorium der Eötvös Loránd-Universität. Ann. Univ. Sci. Budapest. E. Eötvös nom. Sec. Biol. 3: 131-135.

FeHÉr, D. (1954) - Talajbiologia (Soil Biology). 1-1264.

GeBнARDT, A. (1934) - Az abaligeti barlang élövilága (The Biota of the Cave of Abaliget). 1-196.

JAKUTs, L. (1959) - A Béke barlang gyógyhatásának elsö eredményei (The First Results of the Curing Effects of the Peace Cave). Term. Tud. Közl. 90: 20-22.

Kol, E. (1964) - The Microvegetation of a Small Ice Cave in Hungary. Intern. J. Speleol. 1: 19-24.

Palik, P. (1960a) Study of the Algal Flora of Caves. Hidr. Közl. 5: 417-422. - (1960b) - A New Blue-green Alga from the Cave Baradla Near Aggtelek. Ann. Univ. Sci. Budapest, R. Eötvös nom. Sect. Biol. 3: 275-285. 
PALIK, P. - (1961) - Beiträge zur Fortpflanzung der Gomontiella subtubulosa Teodoresco und ein neueres Vorkommen der Species. Nova Hedwigia 3: 81-84.

- (1964a) - Eine neue Aulakochloris-Art aus der Tropfsteinhöhle von Aggtelek. Intern. J. Speleol. 1: 25-28.

- (1964b) - Über die Algenwelt der Höhlen in Ungarn. Intern. J. Speleol. 1: $35-43$.

Prát, S. (1925) - Das Aeroplankton neu geöffneter Höhlen. Zentralbl. Bakterbiol., II. Abt. 64: 39-42.

Prát, S., and Sesták, Z. (1959) - Autotroph-heterotroph Relationships in Natural Waters. Biol. Plant. 1: 81-92.

Radais, N. (1900) - Sur la culture pure d'une algue verte, formation de Chlorophylle à l'obscurité. C. R. Acad. Sci. Paris 130: 12.

Suba, E. (1957) - Die Algen der Pálvölgyer Höhle in Ungarn. Verh. Zool.Bot. Ges. Wien 97: 87-110. 
TABLE I.

DEVELOPMENT OF ALGAL STRAINS IN LABORATORY DARKNESS FOLLOWED BY CULTURING IN LIGHT

Algal strains

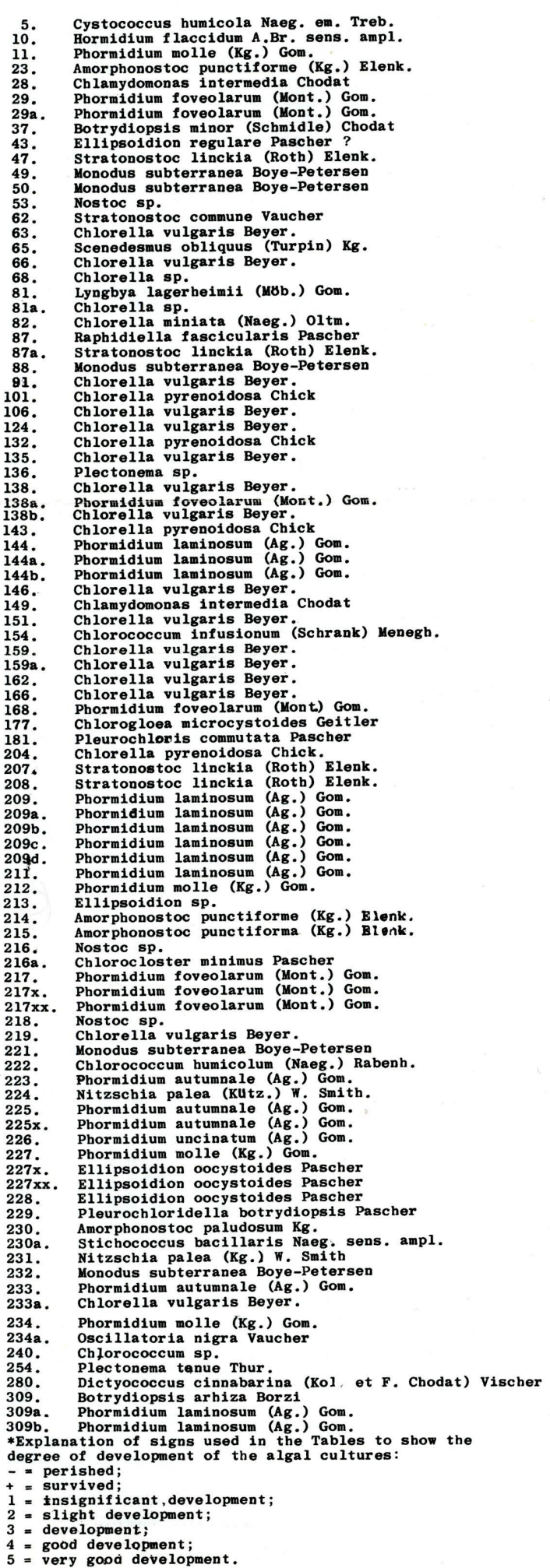

Darkness, 268 days
January 22, 1960 - October 18, 1960

Measurement of

Color of
a lgal thalli
Light, 150 days
Oc tober 18, 1960 - June 25, 1961

Development
algae

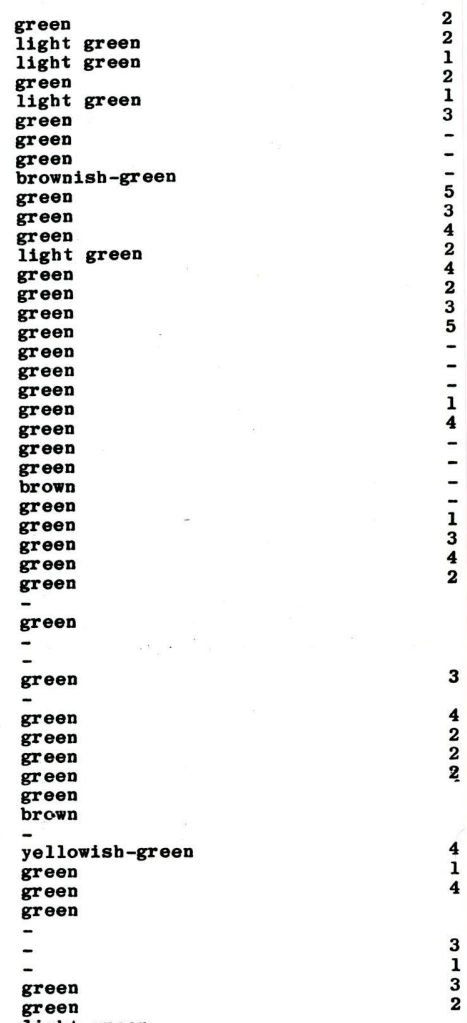

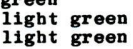

green

green

green

green 3

green

green

$\underset{\text { green }}{\text { green }}$

green

green

green

green
green

light green

light green

light green

green
green

green

green
green

green

green
green

green

green

green

ish-green

green
green

green
green

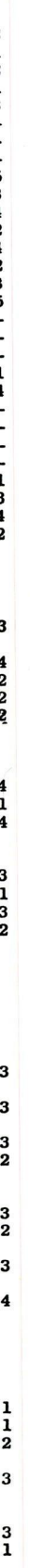




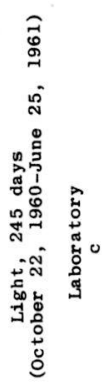
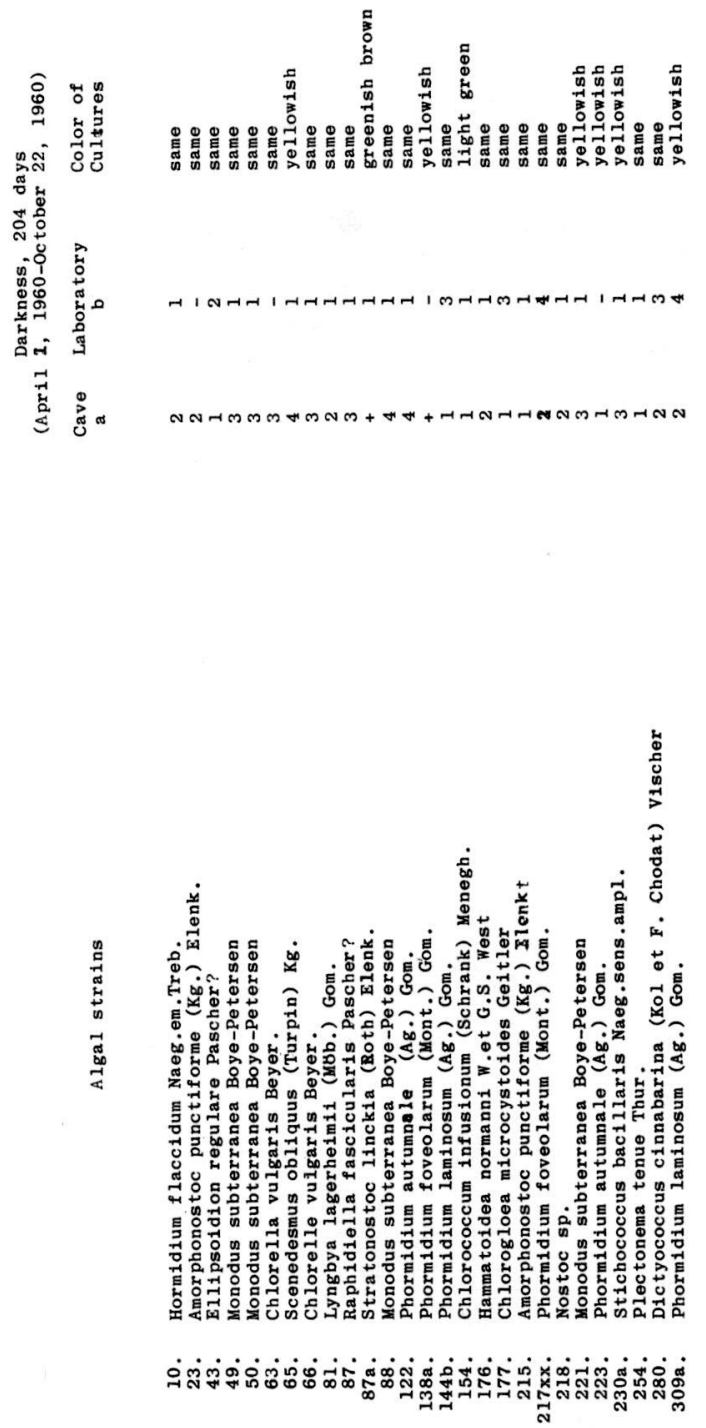


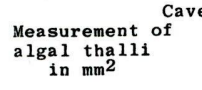

Color
5. Cystococcus humicola Naeg.em.Treb.

10. Hormidium flaccidum $A$. Br. sens. ampl.

11. Phormidium molle (Kg.) Gom. $\mathrm{Kg}$.) Elenk.

28. Chlamydomonas intermedia Chodat

29. Phormldium foveolarum (Mont.) Gom.

29a. Phormidium foveolarum (Mont.) Gom.

43. Ellipsoidion regulare Pascher?

47. Stratonostoc linckia (Roth) Elenk.

49. Monodus subterranea Boye-Petersen

53. Nostoc $\mathrm{sp}$

62. Stratonos toc commune (Vaucher) Elenk.

63. Chlorella vulgaris Beyer.

81. Chlorella vulgaris Beyer.) Gom.

81a. Chlorella sp.

82. Chlorella miniata (Naeg.) oltm.

87. Raphidiella fascicularis Pascher?

87. Stratonostoc linckia (Roth) Elenk.

91. Chlorella vulgaris Beyer

101. Chlorella pyrenoidosa Chick

106. Chlorella vulgaris Beyer.

122. Phormidium autumnale (Ag.) Gom.

124. Chlorella vulgaris Beyer.

132. Chlorella pyrenoidosa Chic

136. Plectonema sp.

138. Chlorella vulgaris Berer.

138a. Phormidium foveolarum (Mont.) Gom.

138b. Chlorella vulgaris Beyer

143. Chlorella pyrenoidosa Chick

144. Phormidium laminosum (Ag.) Gom.

144a. Phormidium laminosum (Ag.) Gom.

146. Chlorella vulgaris Beyer.

149. Chlamydomonas intermedia.

154. Chlorococcum infusionum (Schrank) Menegh

159. Chlorella vulgaris Beyer.

162. Chlorella vulgaris Beyer.

Chlorella vulgaris Beyer.

168. Phormidium foveolarum (Mont.) Gom.

172. Phormidium foveolarum (Mont.) Gom.

174. Ankistrodesmus falcatus (Corda) Ralfs

176. Hamma toidea normanni W. et G.S. West

181. Plouroch

201. Plour us dactylococcoida

01. Chlorella pyrenoidosa Chick

05. Chlorella sp.

206. Phormidium laminosum (Ag.) Gom.

207. Stratonostoc linckia (Roth) Elenk.

208. Stratonostoc linckia (Roth) Elenk.

209a. Phormidium laminosum (Ag.) Gom.

209b. Phormidium laminsum (Ag.) Gom.

209c. Phormidium laminosum (Ag.) Gom.

209d. Phormidium laminosum (Ag.) Gom.

209e. Phormidium laminosum (Ag.) Gom.

211. Phormidium laminosum (Ag.) Gom.

211a. Phormidium laminosum (Ag.) Gom.

213. Ellipsoidion sp.

13a. Ellipsoidion

214. Amorphonos toc punctiforme (Kg.) Elent.

215. Amor phonos

16a. Chlorocloster minimus Pascher

217. Phormidium foveolarum (Mont.) Gom.

217xx. Phormidium foveolarum (Mont.) Gom.

218. Nostorium.

219. Chlorella vulgaris Beyer.

221. Monodus subterranea Boye-Petersen

222. Chlorococcum bumicolum (Naeg.) Rabenh.

223. Phormidium autumnale (Ag.) Gom.

224. Nitzschia palea (Kg.) W. Smith

225. Phormidium autumnale (Ag.) Gom.

226. Phormidium uncinatum (Ag.) Gom.

227. Phormidium molle (Kg.) Go

227x. Ellipsoidion oocystoides Pascher

7xx. Ellipsoidion oocystoides pascher

Pleurochloridella botrydiopsis Pasche

230. Amorphonos toc paludosum (Kg.) Elenk.

231. Nitzschia palea (Kg.) W. Smith

232. Monodus subterranea Boye-Peterse

233. Phormidium autumnale (Ag.) Gom.

233a. Chlorella vulgaris Beyer.

280. Dictyococcus cinnabarina (Kol et F. Chodat) Vischer

309. Botrydiopsis arhiza Borzi

309a. Phormidium laminosum (Ag.) Gom.

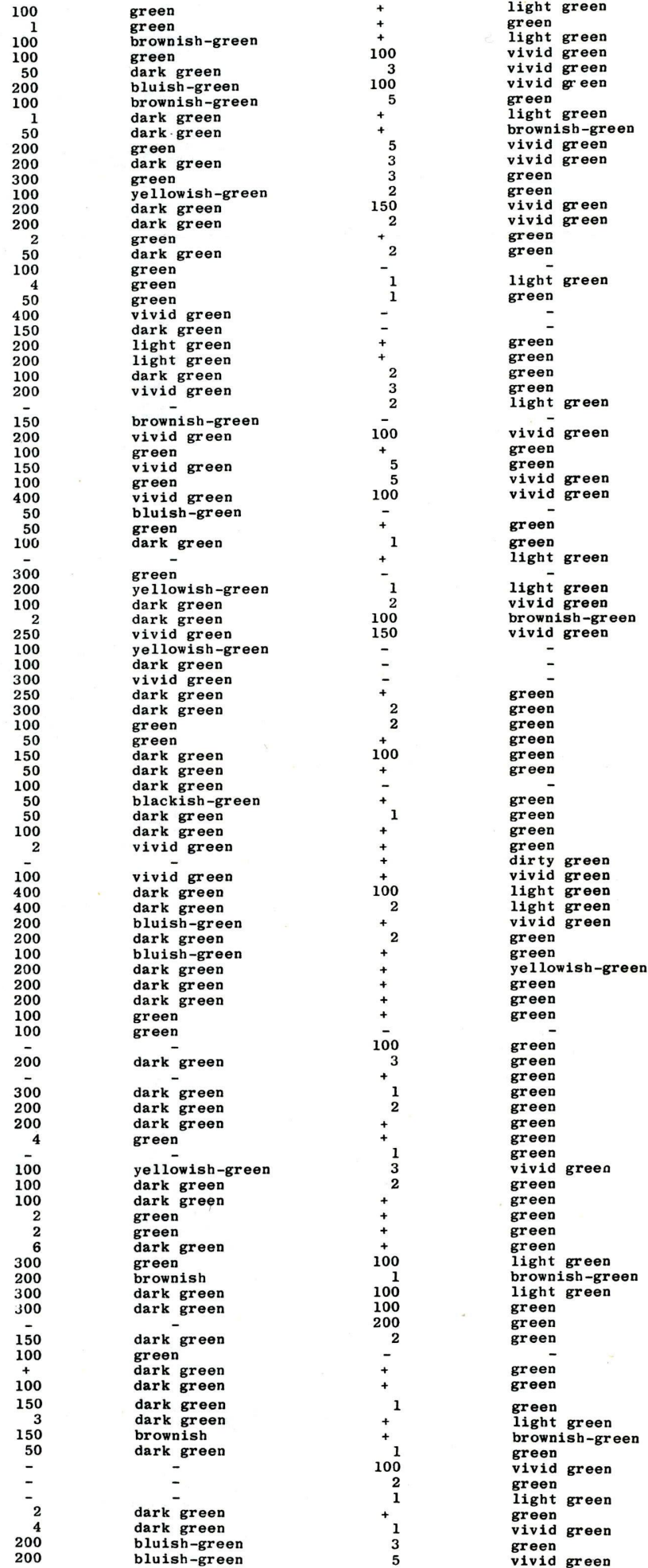




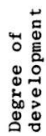

¿ั0

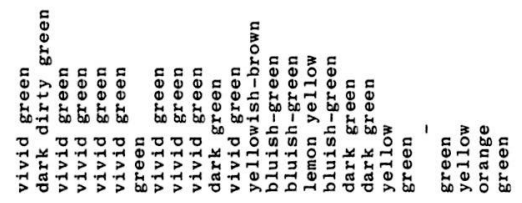

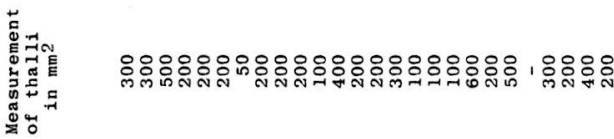

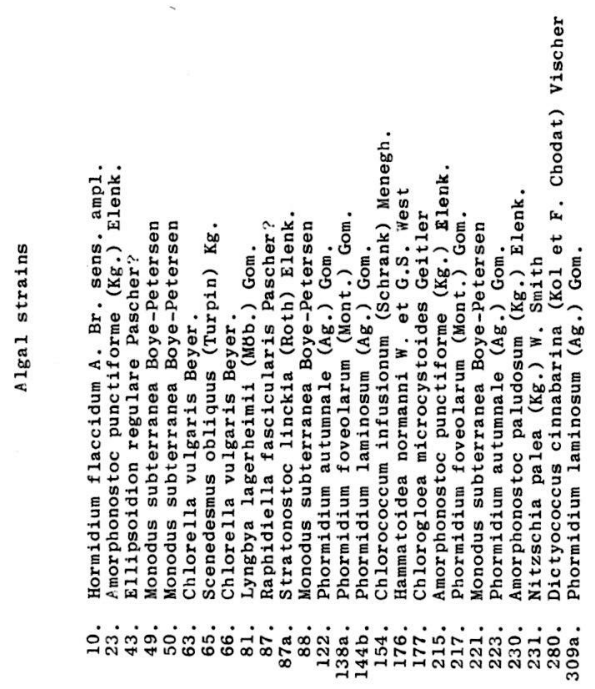


TABLE V

PARALLEL EXPERIMENTS IN CAVE, LABORATORY, CELLAR IN DARKNESS AND LIGHT In Darkness, 420 days (April 25, 1962-June 20, 1963)

In Light, 158 days (June 20, 1963-November 26, 1963)

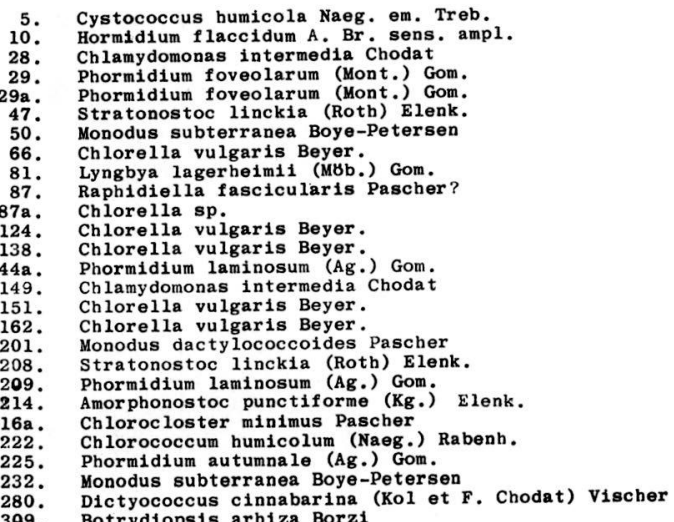

$\begin{array}{cr}+ & 50 \\ 100 & 50 \\ 300 & 100 \\ 300 & 100 \\ 300 & 100 \\ 300 & 200 \\ 300 & 100 \\ 300 & 100 \\ 400 & 300 \\ + & 50 \\ + & 50 \\ + & 50 \\ 200 & 100 \\ + & 20 \\ + & 25 \\ + & 50 \\ + & 25 \\ + & 50 \\ + & 20 \\ + & 50 \\ + & 50 \\ + & 50 \\ 150 & 50 \\ - & - \\ 200 & 50 \\ + & 50\end{array}$


Development of cultures,

\section{In darkness, in the caxe,} Ireely 420 days

$\begin{array}{cr}+ & 50 \\ 300 & 50 \\ 400 & 300 \\ - & - \\ 400 & 250 \\ + & + \\ 200 & 200 \\ + & 25 \\ 100 & 200 \\ + & 50 \\ 200 & - \\ 300 & 300 \\ + & 250 \\ + & - \\ 200 & 50 \\ + & 50 \\ 200 & 50 \\ 200 & 50 \\ + & 50 \\ + & - \\ - & - \\ + & - \\ - & 50 \\ 200 & - \\ 200 & 100 \\ & 50\end{array}$

measurement of thall in $\mathrm{mm}^{2}$

C In darkness In darknes In laboratory indry $\begin{array}{ll}\text { cellar } & \text { cellar } \\ 420 \text { days } & 420 \text { days }\end{array}$

\section{In} darkness 420 days

$\begin{array}{cc}\begin{array}{c}\text { In } \\ \text { In } \\ \text { l1ght }\end{array} & \begin{array}{c}\text { In laborat } \\ \text { In } \\ \text { light }\end{array} \\ 158 \text { days } & 578 \text { days }\end{array}$

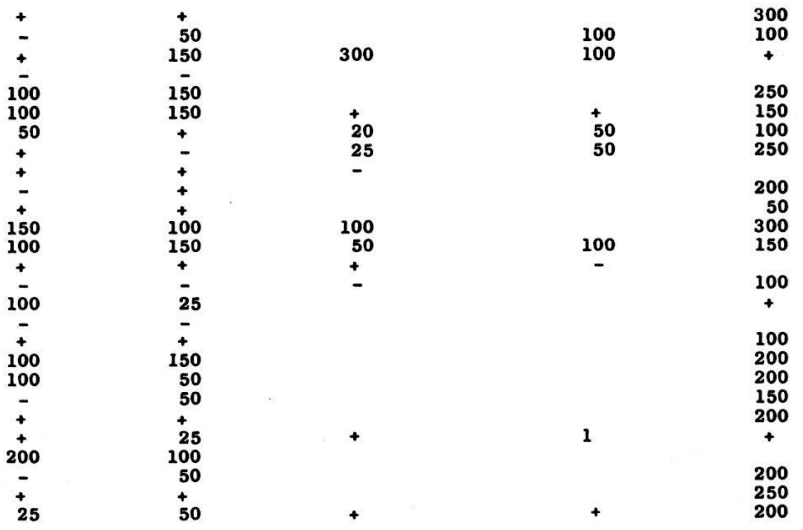

